J. Sci. Univ. Kelaniya 7 (2012) : 43-54

GENETIC VARIATION AND PHYTOTOXIN PRODUCTION

AMONG CYLINDROCLADIUM. QUINQUESEPTATUM ISOLATES

OF HEVEA BRASILIENSIS AND EUGENIA CARRYOPHYLLATA

D.L JAYARATNE ${ }^{1 *}$, B.A.C.DE SILVA ${ }^{1}$ AND W.P.K. SILVA ${ }^{2}$,

${ }^{1}$ Department of Microbiology, University of Kelaniya, Kelaniya, Sri

Lanka

${ }^{2}$ Rubber Research Institute of Sri Lanka

\begin{abstract}
Cylindrocladium quinqueseptatum (Boedijn \& Reitsma 1950) is one of the major plant pathogenic fungi that infects a wide range of plants in humid tropics. The prevailing strains in Sri Lanka cause the foliage and shoot blight diseases and severe defoliation of Hevea brasiliensis (rubber) and Eugenia carryophyllata (clove). The isolates obtained from rubber and clove plants growing in Rathnapura district, in Sabaragamuwa province and Kalutara district, in Western province were evaluated for their toxin activity on hosts and genetic characterization was done using random amplified polymorphic DNA Polymerase Chain Reaction (RAPD-PCR grouping). The analysis of the results using 'Wilcoxon signed-rank test' revealed no correlation among the isolates based on their host or geographical origins. But a relationship was observed between the toxin activity and the RAPD grouping of the isolates. The time course experiment reveled that the minimum toxin activity recorded after three days of inoculation and maximum toxin activity was recorded after nine days of inoculation in Modified Fries Medium (MFM) for all the isolates. Based on the toxin activity and genetic characterization data, the isolates were categorized into two groups. The close genetic relationship
\end{abstract}

\footnotetext{
* Corresponding author Email: jayarat@kln.ac.lk
} 


\section{D.L Jayaratne}

(similarity index $=0.731$ ) and high toxin activity were shown by one group of isolates obtained from cloves grown in Rathnapura with other two groups of isolates obtained from rubber grown in Kalutara. This observation suggests that $C$. quinqueseptatum isolated from clove grown in Rathnapura can be a potential pathogen on rubber.

Keywords: Cylindrocladium quinqueseptatum, RAPD - PCR, phytotoxin, Hevea brasiliensis, Eugenia carryophyllata

\section{INTRODUCTION}

Cylindrocladium quinqueseptatum is one of the most common plant pathogen responsible for epidemic plant diseases in several countries including Australia, India, Vietnam, Laos and Thailand (Old et al. 2003). It causes damping off, root rot, crown canker, seedling, leaf and shoot blight, extensive defoliation and dieback on a wide variety of hosts including ornamental and forest plants and the fungus is widely distributed in the humid tropics (Old et al. 2003, Radziah et al. 1998).

The fungus is a common pathogen of Eucalyptus spp. in Nothern Australia (Pitketheley 1976; Bolland et al. 1985), Brazil (Figueirdo \& Namekata 1967), India (Sharma \& Mohanan 1982; Sharma et al. 1984), Indonesia (Peerally 1974c), Mauritius (Peerally 1974k) and Vanuatu (Ivory et al. 1993). It was reported on Eugenia carryophyllata (Clove) in India (Sarma \& Nambiar 1978), Indonesia (Reitsma \& Sloff 1950) and Sri Lanka (Jayasinghe \& Liyanage 1982) and on Accacia spp. in India (Mohanan \& Sharma 1988). The other plants that have been recorded to host the fungus are Annona squamosa $\mathbf{L}$ in Brazil (Figueirdo \& Namekata 1967), Terminalia paniculata Roth in India (Mohanan \& Sharma 1985) and Camellia sinesis (L) Kuntz. in Mauritius (Peerally 1974c).

In Hevea brasiliensis (rubber), Cylindrocladium quinqueseptatum leaf spot disease was first reported in Peninsular Malaysia in 1972 as a new disease affecting budwood nurseries (Anon 1972). However it remained insignificant until 1990, when it caused defoliation of several clones in budwood nurseries and plantations. The symptoms included shrivelling, blackening and falling off of young leaves, numerous chlorotic pin head like 
leaf spots on mature leaves and purplish and brown leaves surrounded by a prominent yellow halo (Radziah et al. 1988).

In Sri Lanka the fungus Cylindrocladium quinqueseptatum was first recorded as a pathogen in 1982 on Eugenia carryophyllata from Ratnaupra district. The fungus was reported to cause considerable mortality of $E$. carryophyllata seedlings and severe defoliation in young plants (Jayasinghe $\&$ Liyanage 1982). First report of the natural occurrence of Cylindrocladium leaf spot disease of rubber in Sri Lanka was in the year 2003 on the clone RRISL 206 in Kalutara district (Jayasinghe et al. 2003).

The first report on the toxic effect of culture filtrates of $C$. quinqueseptatum is from India on the toxin activity of the Eucalyptus isolate (Anahosur et al. 1976). Subsequently, Kaushik \& Guptha (1991) reaffirmed the findings of Anahosur et al. In 1996 Jayasinghe et al. suggested that the toxin might be considered as a host specific toxin.

The present study was undertaken to investigate the variation of phytotoxin production among the isolates of $C$. quinqueseptatum from $H$. brasiliensis \& E. carryophyllata and to differentiate the isolates using RAPD - PCR (Randomly Amplified Polymorphic DNA - Polymerase Chain Reaction) analysis.

\section{MATERIALS AND METHODS}

\section{Isolation of the pathogen}

Clove and rubber leaves showing typical symptoms of $C$. quinqueseptatum infection, collected from randomly selected rubber and clove plantations in different agro-climatic regions were used for the isolation of the pathogen. A total of 20 diseased leaf samples including ten from each host grown in Kalutara and Rathnapura were used for the isolation of the pathogen into Czepek Dox Agar (CDA) medium. The isolates were cultured on CDA medium at $28 \pm 2{ }^{\circ} \mathrm{C}$ incubation. The conidial and conidiophores morphology of these isolates were used for the identification of $C$. quinqueseptatum grown in CDA. Single spore isolates obtained into Bacto Agar of these cultures were inoculated on CDA and incubated at $28 \pm 2{ }^{\circ} \mathrm{C}$ 


\section{D.L Jayaratne}

under normal light and dark regime for six days were used for this investigation.

\section{Extraction of the toxin}

Erlenmeyer flasks each containing $100 \mathrm{ml}$ of Modified Fries Medium (MFM) (Luck \& Wheeler, 1955) were inoculated with three mycelial plugs, 5 $\mathrm{mm}$ diameter taken from six day old colony of the test fungus grown on CDA. The cultures were incubated at $28 \pm 2^{\circ} \mathrm{C}$ under normal light and dark regime as stationary cultures. After nine days of incubation the cultures were harvested by filtering through $0.22 \mu \mathrm{m}$ Millipore filters. The resulting culture filtrates were used as the source of the toxin.

\section{Detection of the toxin activity}

Detection of the toxin activity and the determination of the time course of toxin production were carried out according to the leaf wilt bio assay technique (Breton et al. 2000). Detached leaflets of eight $H$. brasiliensis clones: RRISL 210, RRISL 217, RRISL 206, RRISL 205, RRISL 211, RRISL 2000, RRIC 121, RRISL 203 were dipped immersing only the leaf petioles in the extracted toxin and incubated at $25{ }^{\circ} \mathrm{C}$ for $12 \mathrm{~h}$ photoperiod. Filtrates obtained from un-inoculated media served as controls. For this experiment, nine replicates from each clone were used. The toxin activity was assessed by the intensity of wilting, which was quantified by the estimation of water loss using the following formula.

$$
\% \text { wilting intensity }=\frac{\mathrm{R}_{\text {control }}-\mathrm{R}_{\text {treated }}}{\mathrm{R}_{\text {control }}} \times 100, \quad \text { where } \mathrm{R}=\frac{\text { Fresh weight }}{\text { Dry weight }}
$$

The time course of toxin production was assessed at $72 \mathrm{~h}$ intervals of incubation for all the isolates. The results were analyzed using the nonparametric procedure NPARIWAY, available in statistical package SAS (SAS, 1987). The statistical method employed was the Kruskal Wallis test and the results were presented in the form sum of ranks. Subsequent paired comparisons were made using Wilcoxon 2 - sample test. 


\section{Genetic characterization of the isolates using Randomly Amplified Polymorphic DNA - Polymerase Chain Reaction (RAPD - PCR) analysis}

DNA extraction from Cylindrocladium quinqueseptatum: Sterile 1.5 $\mathrm{ml}$ Eppendorf tubes filled with $500 \mu \mathrm{l}$ of liquid Potato-dextrose medium were inoculated by hyphal tips taken from single spore isolates of the fungus grown on CDA. The inoculated tubes were incubated at $28 \pm 2{ }^{\circ} \mathrm{C}$ for 72 hours. The mycelial mats of the isolates produced in each tube were pelleted by centrifugation for 5 minutes at $13,000 \mathrm{rpm}$ in a micro-centrifuge. The pellets were washed with TE buffer and crushed in $300 \mu \mathrm{l}$ of extraction buffer (200 mM Tris $\mathrm{HCl} \mathrm{pH}$ 8.5, $250 \mathrm{mM} \mathrm{NaCl}, 25 \mathrm{mM}$ EDTA, 0.5\% SDS) using sterile toothpicks. The DNA was then precipitated according to the sodium acetate-isopropanol precipitation, pelleted by centrifugation for 5 minutes at $13,000 \mathrm{rpm}$ in a micro-centrifuge and washed the pellet in $70 \%$ ethanol. The dried pellets in each tube were re-suspended in $50 \mu 1$ of TE. The presence of DNA was confirmed by agarose gel electrophoresis.

RAPD-PCR were performed in volumes of $25 \mu$ l containing $10 \mathrm{mM}$ Tris- $\mathrm{HCl} \mathrm{pH} 8.3,50 \mathrm{mM} \mathrm{KCl}, 2 \mathrm{mM} \mathrm{MgCl} 2,0.001 \%$ gelatin, $100 \mu \mathrm{M}$ each of dATP, dCTP, dGTP and dTTP, $0.2 \mu \mathrm{M}$ primer (Promega, India), $25 \mathrm{ng}$ of genomic DNA, and 0.5 unit of Taq DNA polymerase. Amplification was performed in a Techne/Flexigene (England) DNA Thermal Cycler programmed for 45 cycles of $1 \mathrm{~min}$ at $94^{\circ} \mathrm{C}, 1 \mathrm{~min}$ at $36^{\circ} \mathrm{C}, 2 \mathrm{~min}$ at $72^{\circ} \mathrm{C}$, using the fastest available transitions between each temperature.

Initially, 20 random 10-mer primers (Promega, India) were screened to select primers exhibiting maximum polymorphism. Of these, 7 primers which produced easily scorable and reproducible banding patterns were used for RAPD analysis of test isolates (Table 1).

DNA amplified products were analyzed by electrophoresis in $1.8 \%$ agarose gels and detected by staining with Ethidium bromide under UV light. Gel was photographed using a digital image capturing device (USB DIGITAL PC-CAMERA). 
Table 1: Oligonucleotide primers used for the RAPD-PCR analysis of Cylindrocladium quinqueseptatum isolates.

\begin{tabular}{|c|c|}
\hline Primer Name & Sequence \\
\hline OPA-04 & AATCGGGCTG \\
\hline OPA-08 & GTGACGTAGG \\
\hline OPA-09 & GGGTAACGCC \\
\hline OPA-11 & CAATCGCCGT \\
\hline OPA-13 & CAGCACCCAC \\
\hline OPA-18 & AGGTGACCGT \\
\hline OPA-20 & GTTGCGATCC \\
\hline
\end{tabular}

\section{Analysis of RAPD}

DNA products were analysed by scoring 1 for the presence of major bands and 0 for their absence. Faint bands that were not clearly resolved were not considered. The discrete data set of 56 bands thus generated was analysed using 'RAPD distance' programme by Nei \& Lei (1979) and a neighbour joining tree was produced (Figure 7). UPGMA (Unweighed Pair Group Method with Arithmetic Mean) method was used to develop the neighbour joining tree.

\section{RESULTS AND DISCUSSION}

Variation among the isolates of $C$. quinqueseptatum from $H$. brasiliensis \& E. carryophyllata in toxin production

Time course of toxin production: Toxin production was first detected after $72 \mathrm{~h}$ of incubation in all isolates. All the isolates had the maximum toxin activity after 9 days of incubation (Figure 1). Hence the extraction of the crude toxin was done after 9 days of incubation to maintain the evenhandedness in the toxin activity assays. 


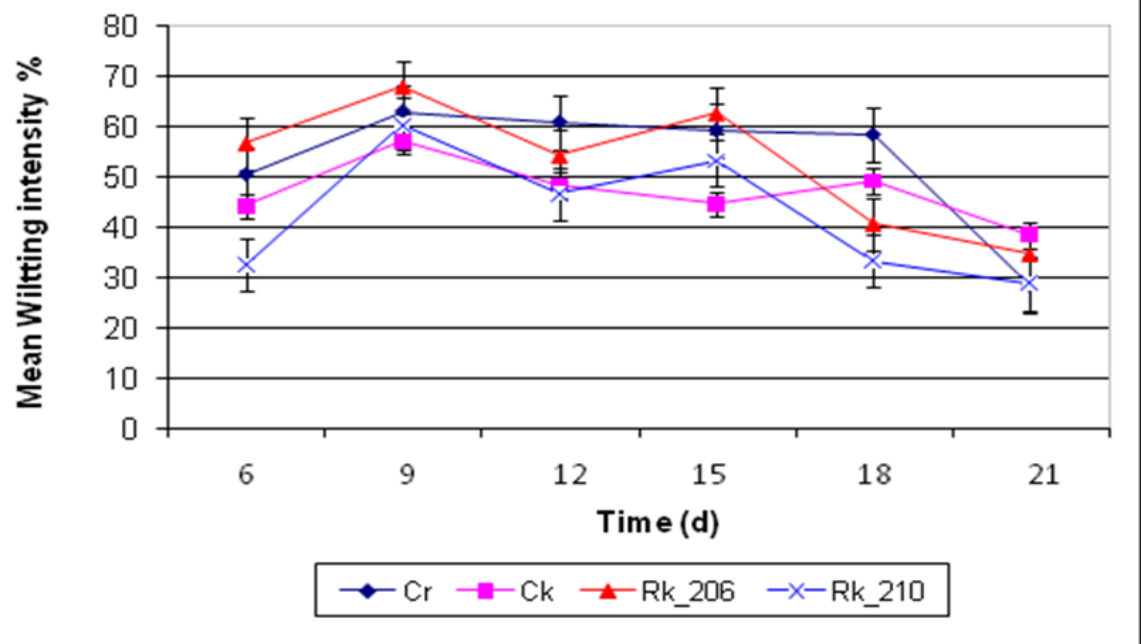

Figure 1: Time course experiment for toxin production of the $C$. quinqueseptatum isolates

Cr: Rathnapura clove isolates; Ck. Kalutara clove isolates; Rk_206. Kalutara rubber isolates from rubber clone RRISL206; Rk_210. Kalutara rubber isolates from rubber clone RRISL210.

Variation of toxin activity among the isolates: Wilting of the rubber leaves was observed with culture filtrates from every isolate after 12 hours. Wilting intensity produced by different isolates on different Hevea clones varied significantly. The Hevea clones, RRISL 206 and RRISL 210 showed higher susceptibility towards the toxins extracted from the isolates Rk-206 and Rk210 respectively (Figure 2). This may be due to the host-pathogen compatibility and an evidence for the production of host specific toxins by $C$. quinqueseptatum isolates. Among all the isolates, Rk-206 had the highest mean wilting intensity indicating the highest toxin activity. Isolates $\mathrm{Cr}$ and Rk-210 showed moderate toxin activities. A mild toxin activity was demonstrated by the isolate $\mathrm{Ck}$. 


\section{D.L Jayaratne}



Figure 2: Variation of toxin activity among the isolates of $C$. quinqueseptatum on Hevea clones

\section{Differentiation of the isolates using Randomly Amplified Polymorphic DNA - Polymerase Chain Reaction (RAPD - PCR) analysis}

The oligonucleotide primers produced reproducible patterns with multiple bright bands and all 7 primers revealed potentially intra-specific polymorphisms among the $C$. quinqueseptatum isolates. The number of amplified DNA fragments generated by individual primers varied from OPA04 to OPA-20, and the sizes of the fragments were in the range 250-4000 bp. A total of 56 DNA fragments were scored and out of these 30 showed polymorphism (Figure 3). 


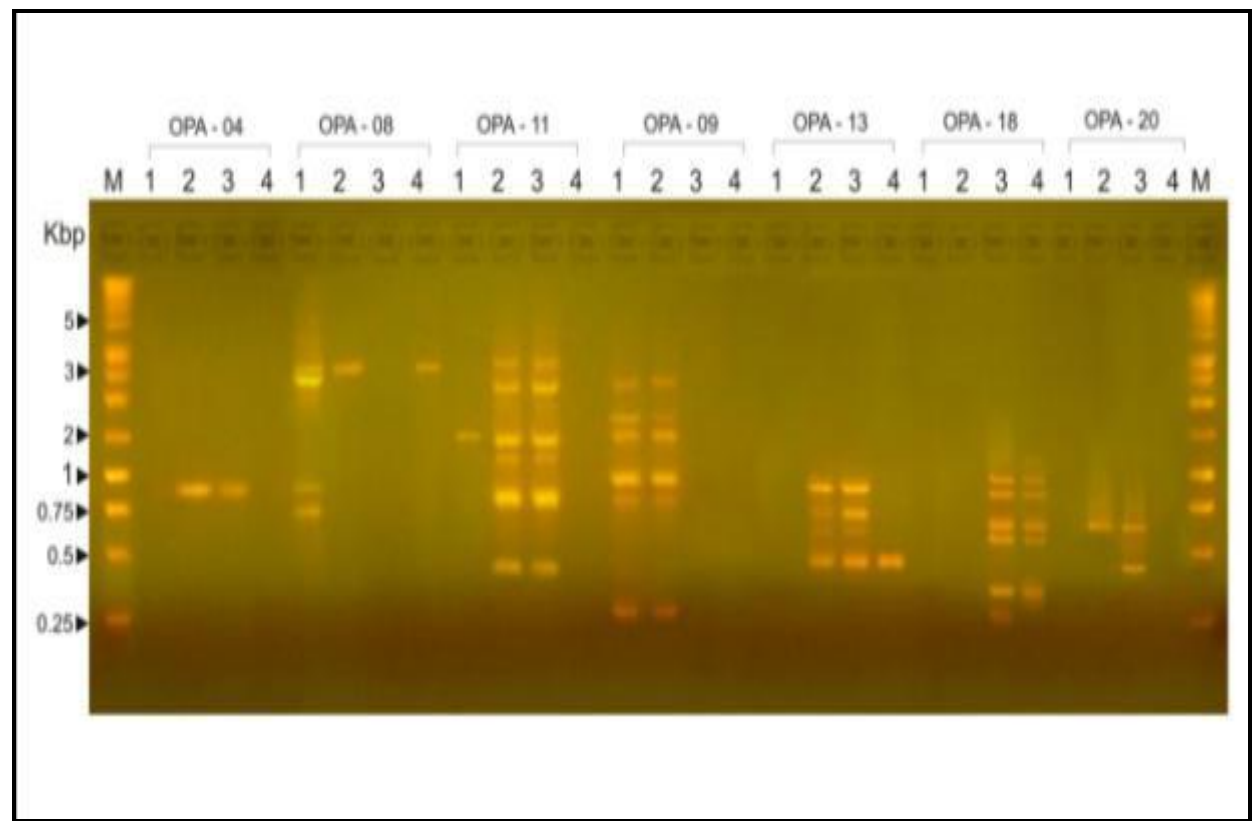

Figure 3: Representative random amplified polymorphic DNA patterns of the four $C$. quinqueseptatum amplified with the primers OPA-04, OPA08, OPA-11, OPA-09, OPA-13, OPA-18, OPA-20. Lanes 1, Ck; lanes 2, Cr; lanes 3, Rk-206; lanes 4, Rk-210, lanes M, 1kb DNA ladder.

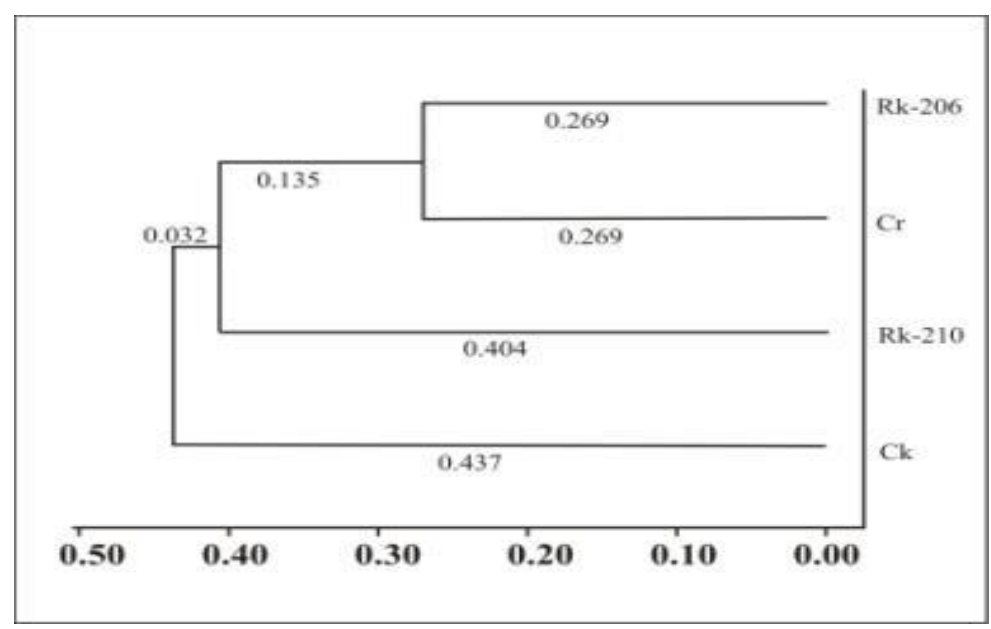

Figure 4: Cluster analysis of the isolates of $C$. quinqueseptatum based on RAPD molecular marker data

Cr: Rathnapura clove isolates; Ck. Kalutara clove isolates; Rk_206. Kalutara rubber isolates from rubber clone RRISL206; Rk_210. Kalutararubber isolates from rubber clone RRISL210. 


\section{D.L Jayaratne}

According to the neighbour joining tree (Figure 4), the isolates $\mathrm{Cr}$ and the isolates Rk-206 seem to be more genetically related than the other isolates. Rk-206, Cr and Rk-210 isolates are clustered together. Ck isolates are the most divergent among the other studied isolates.

These results indicate that no correlation exists among the isolates based on their host or geographical origins. But a relationship can be observed between the toxin activities and the RAPD-PCR grouping of the isolates. Isolates Rk-206, Cr and Rk-210. which demonstrate a close genetic relationship have the highest toxin activities while the isolate $\mathrm{Ck}$, which is distantly related, displays the lowest toxin activity. This correlation may be attributed to a virulent gene for toxin production present in the isolates.

\section{CONCLUSION}

The results reveal that $C$. quinqueseptatum isolates $\mathrm{Cr}$ produced a high mean wilting intensity has a close genetic association with the rubber isolates Rk-206 and Rk-210. Consequently it can be predicted that this strain of $C$. quinqueseptatum isolated from clove can be a potential pathogen for rubber clones. The RAPD-PCR grouping approach using 20 isolates obtained from two different hosts seems to be a useful rapid molecular biological technique for the identification of virulent strains of the pathogen before reaching them to epidemic levels in rubber and clove plantations.

\section{ACKNOWLEDGEMENT}

Authors thank Mr. B.K.A Dias Vijayakumara, Technical Officer of the Department of Microbiology, Faculty of Science, University of Kelaniya and the professionals of the Rubber Research Institute of Sri Lanka. 


\section{REFERENCE}

Anon (1972). A new leaf spot disease of Hevea caused by Cylindrocladium quinqueseptatum. Planters bulletin of rubber research institute of Malaya. 119, 55-56.

Boedijn, K.B. and Reitsma, J. (1950). Notes on the genus Cylindrocladium (Fungi: Mucedinaceae). Reinwardtia. 1, 51-60.

Bolland, L., Tierny, J.W. and Tierny, B.J. (1985). Studies on leaf spot and shoot blight of Eucalyptus caused by Cylindrocladium quinqueseptatum. European journal of forest pathology. 15, 385-397.

Breton, F., Sanier, C., D’auzac, J. 2000: Role of cassiicolin, a host selective toxin in pathogenicity of Corynespora cassiicola, causal agent of a leaf fall disease of Hevea. J. Rubber Res. 3, 115-128.

Figuerdo, M.B. and Namekata, T. (1967). Record of Calonectria quinqueseptata, perfect state Cylindrocladium quinqueseptatumon, Anonas quamosaand Eucalyptus spp. Arquivos do InstitutoBiolgico, 34, 91-96.

Ivory, M.H., Daruhi, G. and Dick, A.M.P. (1993). New leaf diseases of forest trees recorded in Vanuatu. FAO plant protection bulletin. 41, 38-39.

Jayasinghe, C.K. and Liyanage, A. de S. (1982). Leaf spot in clove. Annual review of Rubber Research Institute of Sri Lanka 70.

Jayasinghe, C.K. and Wijesundera, R.L.C. (1999). Toxic metabolite from clove isolate of Cylindrocladium quinqueseptatum. Journal of the rubber research institute of Sri Lanka, 82, 61-71.

Jayasinghe, C.K., Silva, W.P.K. and Nishantha, N. (2003). First report of the natural occurrence of Cylindrocladium leaf spot disease of Sri Lanka. Annual Review 2003 of Rubber Research Institute of Sri Lanka.

Mohanan, C. and Sharma, J.K. (1985). Shot-hole disease of Terminaliapaniculata caused by Cylindrocladium quinqueseptatum-a new record. European journal of forest pathology. 15, 157-159.

Mohanan, C. and Sharma, J.K. (1988). Diseases of exotic occasions in India. 4, 357-361. 


\section{D.L Jayaratne}

Old, K.M., Wingfield, M.J. and Yuan, Z.Q. (2003). Cylindrocladium foliar spot and foliar blight. A manual of diseases of Eucalyptus in South East Asia. 14-18.

Peerally, A. (1974). CMI description of pathogenic fungi and bacteria No. 423. Calonectria quinqueseptatum(conidial state: Cylindrocladium quinqueseptatum).

Peerally, A. (1974c). CMI description of pathogenic fungi and bacteria No. 422. Calonectria quinqueseptatum(Conidial state:Cylindrocladium quinqueseptatum).

Pitkethley, R.N. (1976). Cylindrocladium quinqueseptatum on myrtaceous tree seedlings. Australian plant pathology society newsletter. 5, 57.

Radziah, N.Z. and Chee, K.H. (1988). Cylindrocladium leaf spot. Planters bulletin of rubber research institute of Malaysia. 197, 146-149.

Reitsma, J. and Slooff, W.C. (1950). Leaf diseases of clove seedlings, caused by Gleosporium piperatumE. \& E. and Cylindrocladium quinqueseptatum. Contributions of General agricultural Research station, Bogor, 109, 50-59.

Sarma, Y.R. and Nambiar, K.K.N. (1978). Cylindrocladium leaf rot in clove. Plant disease reporter. 62, 562-564.

Sharma, J.K. and Mohanan, C. (1982). Cylindrocladium spp. associated with various diseases of Eucalyptus in Kerala. European journal of forest pathology, 12, 129-136. 